\title{
PENGARUH DOSIS FRUKTOSA TERHADAP INDEKS MASSA TUBUH, PROFIL GLUKOSA DARAH DAN KADAR TRIGLISERID (Studi pada Tikus Wistar yang Diinduksi High Fat Fructose Diet )
}

\author{
Sunarti $^{1 *}$, Fardhiasih Dwi Astuti ${ }^{1}$,Sufiati Bintanah ${ }^{2}$
}

${ }^{1}$ Fakultas Kesehatan Masyarakat Universitas Ahmad Dahlan Yogyakarta

${ }^{2}$ Program Studi Gizi Universitas Muhammadiyah Semarang

*Email : sunarti@ikm.uad.ac.id

\section{ABSTRACT}

Fructose or often called fruit sugar is one part of simple carbohydrates called monosaccharides (Almatsir 2009). Currently, many food and beverage industries use fructose sugar as a sweetener. (Prahstuti 2011). Consumption of high-fructose products of more than 85 grams per day or more than 25\% of caloric needs can lead to increased triglyceride levels and insulin resistance (Prahastuti 2011). The purpose of this study was to evaluate changes in obesity status, fasting blood glucose levels and triglyceride levels in wistar rats induced with a high fat fructose diet, by giving different doses.

Research methods.The design in this study was a Randomized Control Trial (RCT), double bline pre post control design using male wistar rats, aged 6-7 weeks weighing 90-150 grams, totaling 15 individuals divided into 3 groups. Group 1 is a group of rats fed HFFD with 1\% fructose, group 2 is rats fed HFFD with 2\% fructose, group 3 is rats fed standard feed. Before the treatment, adaptation was carried out for 1 week, after that a pre-test was carried out which included measurements of body weight, body length, fasting data glucose levels, and triglyceride levels. The treatment was given for 60 days, in the middle the measurements of body weight, length, fasting data glucose levels, and triglyceride levels were also carried out. The research location was in the clinical pathology laboratory, Faculty of Pharmacy, Muhammadiyah University, Surakarta.

The results of the study The administration of fructose at a dose of $2 \% / \mathrm{kg} \mathrm{BW}$ increased fasting blood glucose and triglyceride levels higher than the administration of 1\%. kgBB. Upgrade has started since day 30

Keywords: Fructose dose, Body Mass Index, fasting blood glucose level, Triglyceride level, Wistar rats, induced High fat fructose diet

Submitted : 2021-08-13 Accepted : 2021-10-05 Published : 2021-11-08

PENDAHULUAN

Fructosa atau sering disebut gula buah merupakan jenis monosakarida (Mann \& Trusell 2014). Fruktosa merupakan pecahan dari Sukrosa. Saat ini banyak industri makanan maupun minuman yang menggunakan gula fruktosa sebagai pemanis. Umumnya menggunakan perbandingan fructosa $55 \%$ dan glukosa 45\%. (Prahastuti 2011). Konsumsi yang berlebihan pada produk tinggi fruktosa 
lebih dari 85 gram per hari atau lebih dari $25 \%$ kebutuhan energi dapat menyebabkan meningkatkan kadar trigliserid dan resistensi insulin(Prahastuti 2011). Konsumsi tinggi fruktosa juga meningkatkan risiko komplikasi nefrotik diabetik pada penderita diabetes mellitus(Choirunnisa et al. 2019).

Hasil survei pada kelompok remaja dan dewasa menunjukkan rerata konsumsi minuman berkalori $420 \pm 406$ pada remaja, dan $450 \pm 382 \mathrm{kkal}$ per hari(Febriyani et al. 2012). Jika dikonversi dengan asupan fruktosa nilai tersebut melebihi 85 gram fruktosa. Angka ini memberi kontribusi terhadap kelebihan asupan kalori per hari dan berdampak pada obesitas serta komplikasi lainnya. Model penelitian hewan coba, sering menggunakan pendekatan diet high fructose, high sucrose, high fat diet maupun hight fat fructose diet sebagai salah satu cara induksi tikus untuk menjadi sindrom metabolik(Lozano et al. 2016), (Rasool et al. 2018), (Wong et al. 2016). Induksi dengan pendekatan diet lebih dapat memberikan gambaran riel yang terjadi pada manusia.

Penelitian ini merupakan penelitian pendahuluan dengan menggunakan model tikus wistar yang diinduksi dengan pakan high fat fructose diet, dengan memberikan dosis yang berbeda pada komponen fruktosa. Hal yang akan dievaluasi dalam penelitian ini yaitu perubahan status obesitas, kadar glukosa darah puasa dan kadar trigliserid pada tikus percobaan.

Hasil penelitian ini diharapkan dapat memberikan gambaran konsumsi fruktosa dan dampaknya terhadap kesehatan. Hasil penelitian ini juga dapat dijadikan gambaran pada peneliti lain yang akan meneliti terkait sindrom metabolik pada hewan coba.

\section{METODE PENELITIAN}

Design dalam penelitian ini yaitu Randomized Control Trial (RCT), double bline pre post control design. (Sastroasmoro 2011)(Murti 2013). Penelitian ini sudah mendapat persetujuan dari komite etik universitas ahmad Dahlan no 011903009. Tikus yang digunakan dalam penelitin ini adalah tikus wistar jantan, umur 6-7 minggu dengan berat 90150 gram, berjumlah 15 ekor terbagi dalam 3 kelompok. Kelompok 1 yaitu kelompok tikus yang diberi pakan HFFD dengan fruktosa $1 \% \mathrm{BB}$, kelompok ke 2 yaitu tikus yang diberi pakan HFFD dengan fruktosa $2 \% \mathrm{BB}$, kelompok 3 yaitu tikus yang diberi pakan standart. Sebelum perlakuan dilakunan adaptasi selama 1 minggu, setelah itu dilakukan pre test yang meliputi pengukuran berat badan, panjang badan, kadar glukosa data puasa, dan kadar trigliserid. Perlakuan yang diberikan 
selama 60 hari, pada pertengahan dilakukan juga pengukuran berat badan, panjang badan, kadar glukosa data puasa, dan kadar trigliserid. Dan pada akhir perlakuan dilakukan post test untuk mengevaluasi perlakuan yang diberikan.

Lokasi penelitian di laboratorium patologi klinik fakultas Farmasi Universitas Muhammadiyyah Surakarta. Pengukuran bebat badan dengan menggunakan timbangan digital dengan ketelitian 0,1 gram, panjang badan diukur dengan mengukur panjang dari ujung hidung sampai anus(Novelli et al. 2007)(Nesti 2015). Pengukuran obesitas dengan menggunakan IMT dengan membagi berat badan (gr) dibagi kuarat panjang badan $(\mathrm{cm})$. Glukosa darah puasa diukur menggunakan GOD PAP (Anindhita Yuriska 2009), dengan menggunakan standar dikatakan hiperglikemik jika kadar glukosa darah $\geq 126 \mathrm{grm} / \mathrm{dl}$ (Jung et al. 2011). Trigerid diukur menggunakan spektrofotometer. Kadar triglesrid dianggap normal 92,77 $\mathrm{mg} / \mathrm{dl}($ Ihedioha et al. 2013).

\section{HASIL DAN PEMBAHASAN}

Selama perlakuan pada penelitian ini terjadi pengurangan jumlah sample yang disebabkan karena terjadi kematian tikus pada kelompok 1 dan pada kelompok 3 terdapat tikus yang mengalami gangguan metabolik dengan nilai trigliserida yang tinggi melebihi normal. Untuk lebih jelasnya hasil penelitian ini dapat dijelaskan pada gafrik dan tabel berikut :

1. Berat badan Tikus sebelum dan sesudah perlakuan

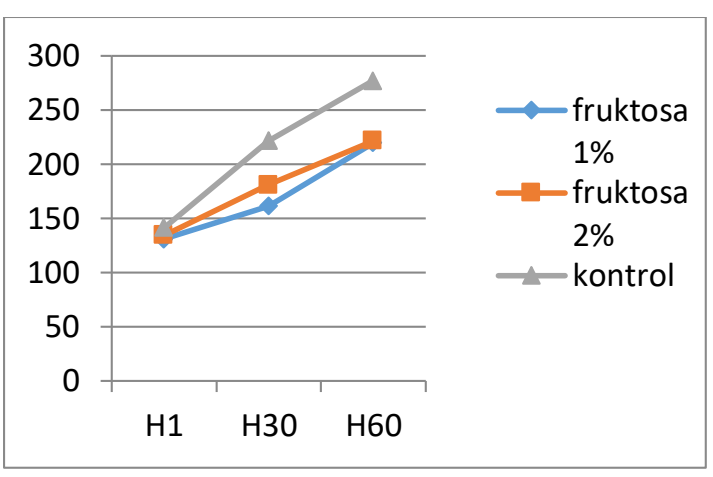

Grafik 1. Berat badan tikus selama percobaan

Berdasarkan grafik tersebut dapat dilihat bahwa pada ketiga kelompok mengalami peningkatan berat badan selama perlakuan dan secara statistik tidak bermakna 
Tabel 1. Panjang Badan tikus berdasarkan kelompok perlakuan

\begin{tabular}{|c|c|c|c|c|}
\hline Kelompok & $\begin{array}{l}\mathrm{PB} 1 \\
(\mathrm{X} \pm \mathrm{SD})\end{array}$ & $\begin{array}{l}\mathrm{PB} 30 \\
(\mathrm{X} \pm \mathrm{SD})\end{array}$ & $\begin{array}{l}\mathrm{PB} 60 \\
(\mathrm{X} \pm \mathrm{SD})\end{array}$ & Delta PB \\
\hline $\begin{array}{l}\text { HFD + } \\
\text { fruktosa 1\% } \\
\text { BB }\end{array}$ & $15,25 \pm 0,50$ & $16,02 \pm 0,63$ & $19,00 \pm 0,40$ & $3,75 \pm 0,288$ \\
\hline $\begin{array}{l}\mathrm{HFD}+ \\
\text { fructose } 2 \%\end{array}$ & $15,10 \pm 0,961$ & $16,40 \pm 1,51$ & $18,3 \pm 1,03$ & $3,20 \pm 0,115$ \\
\hline $\begin{array}{l}\text { Pakan } \\
\text { standart }\end{array}$ & $15,25 \pm 0,64$ & $17,87 \pm 1,1$ & $19,5 \pm 0,40$ & $4,25 \pm 0,115$ \\
\hline$P$ value & 0,98 & 0,1 & 0,122 & 0,151 \\
\hline
\end{tabular}

Berdasarkan tabel 1 dapat diketahui rerata panjang badan tikus tertinggi pada kelompok dengan pakan standar. Dan pertambahan panjang badan tertinggi juga pada kelompok pakan standart, namun secara statistik tidak bermakna.

Tabel 2. Indeks massa tubuh Tikus Sebelum dan sesudah perlakuan

\begin{tabular}{|c|c|c|c|c|}
\hline Kelompok & $\mathrm{IMT}(\mathrm{X} \pm \mathrm{SD})$ & $\begin{array}{l}\text { IMT30(gram) } \\
(\mathrm{X} \pm \text { SD })\end{array}$ & $\begin{array}{l}\text { IMT } \\
60(\text { gram }) \\
(\mathrm{X} \pm \mathrm{SD}) \\
\end{array}$ & Delta IMT \\
\hline $\begin{array}{l}\text { HFD + } \\
\text { fruktosa } \\
1 \% \mathrm{BB}\end{array}$ & $0,48 \pm 0,063$ & $0,58 \pm 0,076$ & $0,60 \pm 0,52$ & $0,118 \pm 0,014$ \\
\hline $\begin{array}{l}\text { HFD + } \\
\text { fructose } 2 \\
\%\end{array}$ & $0,513 \pm 0,037$ & $0,63 \pm 0,037$ & $0,63 \pm 0,08$ & $0,117 \pm 0,094$ \\
\hline $\begin{array}{l}\text { Pakan } \\
\text { standart }\end{array}$ & 0,611 & $0,692 \pm 0,010$ & $0,72 \pm 0,048$ & $0,115 \pm 0,087$ \\
\hline$-p$ & 0,038 & 0,018 & 0,078 & 0,996 \\
\hline
\end{tabular}

Berdasarkan tabel 2 dapat diketahui perubahan nilai IMT pada ketiga kelompok perlakuan tidak berbeda bermakna, tetapi pertambahan tinggi pada kelompok 2 yaitu tikus yang diberi pakan HFFD dengan fruktosa $2 \%$ BB. Nilai IMT yang ditunjukkkan pada tabel 2 pada masingmasing perlakuan tidak berbeda signifikan. Namun demikian perubahan IMT atau delta IMT pada kelompok 1 dan 2 lebih besar dibandingkan kelompok 3. Hal ini menunjukkan adanya kecenderungan bahwa pemberian tambahan fruktusa berpengaruh pada status gizi. Hasil ini berbeda dengan penelitian lozano yang melaporkan bahwa pemberian diet high fructose dan high fat diet meningkatkan berat badan tikus(Lozano et al. 2016). Penelitian ini juga berbeda dengan penelitian hariri et all yang melaporkan pemberian diet tinggi lemak meningkatkan obesitas pada tikus (Hariri \& Thibault 2010). Perbedaan hasil ini mungkin disebabkan karena perbedaan asupan makanan harian pada tikus, namun demikian berdasarkan delta IMT menunjukkan kecenderungan peningkatan IMT yang lebih besar dibandingkan kelompok panakn standart.

Tabel 3. Rerata Glukosa darah Puasa pada hari ke 1, 30 dan 60

\begin{tabular}{lllll}
\hline Kelompok & $\begin{array}{l}\text { Glukosa } \\
\text { puasa } \\
1(\mathrm{X} \pm \mathrm{SD})\end{array}$ & $\begin{array}{l}\text { Glukosa } \\
\text { puasa } 30 \\
(\mathrm{gr} / \mathrm{dl}) \\
(\mathrm{X} \pm \mathrm{SD})\end{array}$ & $\begin{array}{l}\text { Glukosa } \\
\text { puasa } 60 \\
60(\mathrm{~g} / \mathrm{dl}) \\
(\mathrm{X} \pm \mathrm{SD})\end{array}$ & $\begin{array}{l}\text { Delta } \\
\text { glukosa }\end{array}$ \\
\hline $\begin{array}{l}\text { HFD + } \\
\text { fruktosa }\end{array}$ & $83,75 \pm 13,20$ & $101,75 \pm 18,99$ & $136,75 \pm 50,70$ & $53,0 \pm 38,73$ \\
$1 \%$ BB & & & & \\
\hline $\begin{array}{l}\text { HFD + } \\
\text { fructose } 2\end{array}$ & $82,20 \pm 17,90$ & $108,80 \pm$ & $172,60 \pm 72,85$ & 90,40 \\
$\%$ & & 21,67 & & $\pm 85,12$ \\
\hline $\begin{array}{l}\text { Pakan } \\
\text { standart }\end{array}$ & $95,50 \pm 3,19$ & $103,5 \pm$ & $108,75 \pm 17,21$ & $13,25 \pm 18,94$ \\
\hline -p & 0,510 & 0,842 & 0,052 & 0,048 \\
\hline
\end{tabular}

Berdasarkan tabel 3 dapat diketahui rerata kadar glukosa darah puasa tertinggi pada kelompok 2 dan secara statistik mendekati signifikan dengan nilai p 0.052 . Sedangkan perubahan kadar glukosa darah tertinggi pada kelompok 2 dan berbeda signifikan dengan nilai p 0,048.

Dengan pemberian high fat fruktose diet dengan $2 \%$ per $\mathrm{kg} \mathrm{BB}$ menunjukkan 
peningkatan kadar glukosa darah yang lebih tinggi, dengan trend kenaikan dimulai pada hari ke 30 dan pada hari ke 60 , rerata glukosa darah puasa pada kelompok dengan $2 \%$ fruktose lebih tinggi dibanding kelompok lain. Hal ini sesuai dengan terori yang mengatakan induksi dengan fruktosa mampu meningkatkan kadar glukosa darah pada tikus percobaan(Zhuhua et al. 2015). (Velez et al. 2014).

Tabel 4. Rerata Trigliserid pada tikus hari1, 30 dan 60

\begin{tabular}{lllll}
\hline Kelompok & $\begin{array}{l}\text { Trigliserid } \\
1(\mathrm{X} \pm \mathrm{SD})\end{array}$ & $\begin{array}{l}\text { Trigliserid 30 } \\
(\mathrm{gr} / \mathrm{dl}) \\
(\mathrm{X} \pm \mathrm{SD})\end{array}$ & $\begin{array}{l}\text { Trigliserid 60 } \\
60(\mathrm{~g} / \mathrm{dl}) \\
(\mathrm{X} \pm \mathrm{SD})\end{array}$ & $\begin{array}{l}\text { Delta } \\
\text { trigliserid }\end{array}$ \\
\hline $\begin{array}{l}\text { HFD + } \\
\text { fruktosa } 1 \%\end{array}$ & $63,75 \pm 12,73$ & $90,25 \pm 32,81$ & $112,75 \pm 30,84$ & $49,00 \pm 26,69$ \\
BB & & & & \\
\hline $\begin{array}{l}\text { HFD + } \\
\text { fructose 2 } \%\end{array}$ & $95,60 \pm 25,98$ & $156,60 \pm 56,60$ & $151,00 \pm 48,02$ & $56,20 \pm$ \\
\hline $\begin{array}{l}\text { Pakan } \\
\text { standart }\end{array}$ & $118,25 \pm 42,75$ & $139,35 \pm 49,45$ & $84,50 \pm 51,22$ & $-33,75 \pm$ \\
\hline -p & 0,072 & 0,164 & 0,130 & 0,028 \\
\hline
\end{tabular}

Berdasarkan tabel 4 dapat diketahui kadar trigserid pada kelompok 2 mengalami peningkatan yang signifikan, diikuti kelompok 1 dan secara statistik bermakna. Sementara pada kelompok 3 kadar trigerid akhir mengalami penurunan. Kelompok 2 mengami peningkatan kadar trigliserid mulai hari ke 30. Perubahan trigliserid sebelum dan sesudah perlakuan pada ketiga kelompok berbeda signifikan dengan nilai $\mathrm{p} 0,028$.

Kenaikan kadar trigliserid pada kelompok tikus dengan $2 \%$ fruktosa lebih tinggi dibandingkan yang kelompok perlakuan lain. hal ini sesuai dengan teori yang menyebutkan bahwa diet tinggi fruktosa akan meningkatkan kadar trigliserid.(Zhuhua et al. 2015)(Prahastuti 2011).

\section{UCAPAN TERIMA KASIH}

Ucapan terima kasih kepada : Rektor UAD, atas dukungan dana dan fasilitas pada penelitian ini. Penelitian ini telah memperoleh ijin etik dari komite etik Universitas Ahmad Dahlan no 011903009

\section{KESIMPULAN DAN SARAN}

\section{Kesimpulan}

Pemberian fruktosa dosis $2 \% / \mathrm{kg}$ BB meningkatkan kadar glukosa darah puasa dan trigliserid lebih tinggi dibandingkan pemberian $1 \%$. kgBB. Peningkatan sudah diawali sejak hari ke 30 .

\section{Saran}

Perlu dilakukan penelitian lanjutan pengaruh pemberian formula tepung tempe dan bekatul terhadap kadar gula darah pada wanita menopause dislipidemia.

\section{DAFTARPUSTAKA}

Anindhita Yuriska, 2009. Efek Aloksan Terhadap Kadar Glukosa Darah Tikus Wistar. Fakultas Kedokteran Universitas Diponegoro Semarang, pp.1-45.

Choirunnisa, H. et al., 2019. Pengaruh Asupan Tinggi Fruktosa Terhadap Komplikasi Nefropati Diabetik Pada 
Penderita Diabetes Mellitus The Effect High Intake of Fructose On Complication Diabetic Nephropathy In Patients Diabetes Mellitus. Medula, 9(10), pp.314-322.

Desmawati, D., 2017. Pengaruh asupan tinggi fruktosa terhadap tekanan darah. Majalah Kedokteran Andalas, 40(1), p.31.

Febriyani, N.M.P., Hardinsyah \& Briawan, D., 2012. Minuman berkalori dan kontribusinya terhadap total asupan energi remaja dan dewasa. , 7(1), pp.35-42.

Hariri, N. \& Thibault, L., 2010. High-fat diet-induced obesity in animal models. Nutrition Research Reviews, 23(2), pp.270-299.

Ihedioha, J.I., Noel-Uneke, O.A. \& Ihedioha, T.E., 2013. Reference values for the serum lipid profile of albino rats (Rattus norvegicus) of varied ages and sexes. Comparative Clinical Pathology, 22(1), pp.93-99.

Jung, J.Y. et al., 2011. Onion peel extracts ameliorate hyperglycemia and insulin resistance in high fat diet/streptozotocin-induced diabetic rats. Nutrition and Metabolism, 8, pp.1-8.

Lozano, I. et al., 2016. High-fructose and high-fat diet-induced disorders in rats: Impact on diabetes risk, hepatic and vascular complications. Nutrition and Metabolism, 13(1), pp.1-13. Available at: http://dx.doi.org/10.1186/s12986016-0074-1.

Mann, J. \& Trusell, A.S., 2014. Essential of Human Nutrition A. Hartono, ed., EGC.

Murti, B., 2013. Prinsip dan Metode Riset Epidemiologi,

Nesti, D.R., 2015. Imunoreaktif Insulin dan Glukagon pada Pankreas Tikus ( Rattus norvegicus ) Obesitas. In Tesis.

Novelli, E.L.B. et al., 2007. Anthropometrical parameters and markers of obesity in rats. Laboratory Animals, 41(1), pp.111-119.

Prahastuti, S., 2011. Konsumsi Fruktosa Berlebihan dapat Berdampak Buruk bagi Kesehatan Manusia Consuming Excessive Amount of Fructose may Affect Our Health. Jkm, 10(2), pp.173-189.

Rasool, S. et al., 2018. High Fat With High Sucrose Diet Leads to Obesity and Induces Myodegeneration. , 9(September), pp.1-10.

Sastroasmoro, S.I.I., 2011. Dasar-Dasar Metodologi Penelitian Klinis, Jakarta: 
Sagung Seto.

Velez, M., Kohli, S. \& Sabbah, H.N., 2014. Models of Insulin Resintance and Heart Failure. , 19(1), pp.1-23.

Wong, S.K. et al., 2016. Animal models of metabolic syndrome: a review. Nutrition \& Metabolism, 13(1), p.65. Available at: http://nutritionandmetabolism.biome dcentral.com/articles/10.1186/s12986 -016-0123-9.

Zhuhua, Z. et al., 2015. A novel mice model of metabolic syndrome: the high-fat-high-fructose diet-fed ICR mice. Experimental Animals, 64(4), pp.435-442. Available at: https://www.jstage.jst.go.jp/article/ex panim/64/4/64_14-0086/_article. 
Jurnal Gizi 10 (2) 2021 